\title{
Nickel Adsorption by Variable Charge Soils: Effect of pH and Ionic Strength
}

\author{
Marcio Roberto Soares ${ }^{*}$, José Carlos Casagrande and Ernesto Rinaldi Mouta \\ Departamento de Recursos Naturais e Proteção Ambiental; Centro de Ciências Agrárias; Universidade Federal de \\ São Carlos; C.P.: 153; 13600-970; Araras - SP - Brasil
}

\begin{abstract}
The effects of $p H$ and ionic strength (I) on Ni adsorption in variable charge soils were evaluated by laboratory batch experiments. Experimental results fitted the Langmuir model. Maximum adsorption (Ads $s_{\max }$ ) ranged from $260-$ $2818 \mathrm{mg} \mathrm{kg}^{-1}$ (topsoil) to 532-1541 $\mathrm{mg} \mathrm{kg}^{-1}$ (subsoil). Nickel affinity $\left(K_{L}\right)$ was higher in the subsoil samples $(0.022-$ $\left.0.236 \mathrm{~L} \mathrm{~kg}^{-1}\right)$ than in topsoil (0.003-0.049 $\left.\mathrm{L} \mathrm{kg}^{-1}\right)$. Adsorption envelopes showed sharp increase in Ni adsorption (20$90 \%)$ in the 4.0-6.0 pH range. Nickel adsorption was affected by I and specific adsorption predominated in the 3.0$5.0 \mathrm{pH}$ range, while above $\mathrm{pH}$ 5.0, it was adsorbed by electrostatic mechanisms. Negative values of free energy variation $(\Delta G)$ and the separation factor $K_{R}<1$ indicated that Ni adsorption reaction was favorable and occurred spontaneously, especially when $\mathrm{pH}$ increase. Chemical and mineralogical soil attributes should be considered as criteria for selecting the areas for disposal of residues containing Ni to minimize the impact on the environment.
\end{abstract}

Key words: adsorption isotherms; free energy; adsorption envelopes; adsorption edges; ionic strength

\section{INTRODUCTION}

Nickel (Ni) is a heavy metal whose natural content in the soil can vary from very small proportions $\left(<5 \mathrm{mg} \mathrm{kg}^{-1}\right)$, which qualify it as a trace element, to excessively high concentrations $\left(5000 \mathrm{mg} \mathrm{kg}^{-1}\right)$, found in the soils formed on ultrabasic igneous rocks (Rovers et al., 1983; Uren, 1992). Plants require $\mathrm{Ni}$ because the element acts as a urease activator, which breaks urea into carbonic gas and ammonia (Eskew et al., 1983). Over the years, the quantity of $\mathrm{Ni}$ released in the soil has increased due to the high production, processing and recycling of $\mathrm{Ni}$ and its byproducts and residues. Nickel is very important in the electronics sector, in the production of $\mathrm{Ni}-\mathrm{Cd}$ batteries and in the galvanoplasty industry, where it is used to improve the resistance and the heat and mechanical properties of more than 3000 metal alloys (Sunderman and Oskarsson, 1991). Chronic exposure to $\mathrm{Ni}$ can affect the cardiovascular and respiratory systems, skin and liver, in addition to enhancing the teratogenic and carcinogenic effect of the element (Denkhaus and Salnikow, 2002).

Mobility and bioavailability of $\mathrm{Ni}$ in the soil depend on its concentration at the liquid phase. The entry of the element in the food chain can be facilitated by absorption and translocation by the plants or by leaching to the underground water sheets. Its persistence in the soil and reduction in mobility involve the phenomena of sorption, desorption, precipitation, complexing, oxireduction and dissolution. Although all these reactions can occur simultaneously, adsorption

*Author for correspondence: mrsoares@ cca.ufscar.br 
mechanisms are known to be determinant in the control of metal availability and solubility in the soil (Sparks, 1999). Interest has grown recently in the phenomena of metallic ion adsorption by surfaces with $\mathrm{pH}$-dependent charges to increase the understanding of the dynamic of these contaminants in the environments of tropical region. In these systems, dependence of adsorption in relation to the variations in the soil solution parameters, such as $\mathrm{pH}$ and ionic strength, is determinant for understanding the chemical performance of metals in the soil, from the agricultural, environmental and public health points of view (Uren, 1992).

The $\mathrm{pH}$ is the primary factor that controls heavy metal adsorption and their availability (Harter, 1983; Casagrande et al., 2008). However, residues and effluents applied to the soil may contain a series of specific chemicals in solution (Tamanini et al., 2008) and the electrolytic concentration is frequently higher than that found in the soil solution (Bowman et al., 1981). The dependence of adsorption with regard to ionic strength is used to distinguish the outer- and inner-sphere adsorption mechanisms, which informs the stability and intensity of the retention process (Petruzzelli et al., 1985; Kosmulski, 1997; Criscenti and Sverjensky, 1999). This aspect is of particular interest for $\mathrm{Ni}$ adsorption, because there is no consensus yet on its retention mechanism by the soil.

Nickel adsorption has been studied in pure systems, such as $\mathrm{Fe}, \mathrm{Al}$ and $\mathrm{Mn}$ hydrated oxides (McKenzie, 1980; Beukes et al., 2000), clay minerals (Mattigod et al., 1979; Echeverría et al., 2003; Sen Gupta and Bhattacharyya, 2006) and organic matter (Mellis et al., 2004), and in complex systems such as the soil, under natural and agricultural conditions or with residue application (Camargo et al., 1989; Pombo et al., 1989; Mellis et al., 2004; Iglesias et al., 2007). However, sufficient data have not yet been gathered on $\mathrm{Ni}$ adsorption by weathered soils of the wet tropics to assure the implementation of efficient prevention techniques and remediation of soil contamination.

Reactions between the heavy metals and soil have been described mathematically by adsorption isotherm equations that describe the ratio between the adsorbed and in solution metal concentration. This approach gives quantitative parameters of the adsorption reaction, supplying important data on the retention capacity and the force by which the metal is retained by the soil (Morera et al., 2001). The Langmuir isotherm, fitted by nonlinear models, was successfully applied in the study of metals in Oxisols, including $\mathrm{Ni}$ (Camargo et al., 1989; Pombo et al., 1989). However, metal adsorption modeling in tropical soils is rarely accompanied by a more detailed description, based on thermodynamics concepts (Silveira et al., 1999; Dias et al., 2003; Soares et al., 2005; Iglesias et al., 2007; Casagrande et al., 2008; Mouta et al., 2008; Soares et al., 2009). Some information has been obtained on thermodynamic modeling for the adsorption reaction of some metallic ions by homogeneous surfaces, such as kaolinite and oxidic interfaces (James and Healy, 1972; Angove et al., 1999; Trivedi and Axe, 2000), but there are few data on the thermodynamics of the $\mathrm{Ni}$ adsorption reaction in the soils (Sen Gupta and Bhattacharyya, 2006). As metal distribution among the liquid and solid phases is a measure of the position of equilibrium in the adsorption process, the state of this system can be defined by a set of thermodynamic properties that can serve as measures of the extension and spontaneity of the adsorption reaction (Soares et al., 2005; Casagrande et al., 2008).

The objectives of this study were to investigate the parameters of the $\mathrm{Ni}$ adsorption reaction by the soils with predominantly $\mathrm{Fe}$ and $\mathrm{Al}$ (oxy)hydroxides in their mineralogy and to assess the directional force of this reaction by studying the thermodynamic parameters in function of the variation in soil solution $\mathrm{pH}$ and ionic strength.

\section{MATERIALS AND METHODS}

\section{Soils}

In order to study Ni adsorption, topsoil (0-0.2 m) and subsoil samples (the greatest expression of the $B$ horizon diagnostic) of two Oxisols [heavy clayey-textured Anionic "Rhodic" Acrudox (RA); medium-textured Anionic "Xanthic" Acrudox (XA)] and one Alfisol [heavy clayey-textured Rhodic Hapludalf (RH)] (Soil Survey Staff, 1999) derived from basalt and collected in locations in São Paulo State, Brazil (Ribeirão Preto $-21^{\circ} 10^{\prime} S$, $47^{\circ} 48^{`} \mathrm{~W}$; Guaíra - $20^{\circ} 19^{\prime} \mathrm{S}, 48^{\circ} 18^{\prime} \mathrm{W}$; Araras $22^{\circ} 20^{\prime} \mathrm{S}, 47^{\circ} 27^{\prime} \mathrm{W}$ ) were used.

\section{Soil characterization}

Routine chemical, physical and mineralogical characterization of the soil samples was performed 
in fine air-dried soil samples, sieved through $2 \mathrm{~mm}$ mesh, according to well established methods described in Camargo et al. (1986) and Raij et al. (2001). pH was determined by potenciometry in $\mathrm{H}_{2} \mathrm{O}$ and in $1 \mathrm{~mol} \mathrm{~L}^{-1} \mathrm{KCl}$ suspensions with 1:2.5 soil:solution ratio, and the difference $\Delta \mathrm{pH}=\mathrm{pH}_{\mathrm{KCl}}$ $-\mathrm{pH}_{\mathrm{H} 2 \mathrm{O}}$ was used as estimate of the net charge balance (Mekaru and Uehara, 1972). The zero point of salt effect (ZPSE) represented the $\mathrm{pH}$ value at the point of intersection of the titration curves with $\mathrm{H}^{+}$and with $\mathrm{OH}^{-}$, at three $\mathrm{KCl}$ concentrations $\left(0.1 ; 0.01\right.$ and $\left.0.001 \mathrm{~mol} \mathrm{~L}^{-1}\right)$ (Alleoni and Camargo, 1994). Samples were also investigated using the cesium $\left(\mathrm{Cs}^{+}\right)$adsorption method, which measured the structural permanent and variable charges and was based on the preference of $\mathrm{Cs}^{+}$over $\mathrm{Li}^{+}$in the siloxane surface sites and the lower selectivity of ionizable surface group for the Cs ion (Weber et al., 2005). The BET $\mathrm{N}_{2}$ adsorption method was used to measure the specific surface area (SSA) (Feller et al., 1992). Kaolinite and gibbsite contents were semiquantified by differential termal analysis (DTA) of the deferrified clay fraction without organic matter of the soil samples (Tan et al., 1986).

\section{Batch mode adsorption studies}

Laboratory batch mode adsorption experiments were carried out according to Soares and Casagrande (2009), after adding $20 \mathrm{~mL}$ of $\mathrm{Ca}\left(\mathrm{NO}_{3}\right)_{2}$ electrolytic solution containing $\mathrm{Ni}$ in the form of hydrated nitrate salt $\left[\mathrm{Ni}\left(\mathrm{NO}_{3}\right)_{2} \cdot 6 \mathrm{H}_{2} \mathrm{O}\right]$ at 2 $\mathrm{g}$ of fine air-dried soil samples, maintaining the 1:10 soil:solution ratio. The set was placed in polyethylene flasks under agitation $(150 \mathrm{rpm})$ for $24 \mathrm{~h}$ at $24 \pm 2^{\circ} \mathrm{C}$. After equilibration, suspensions were then centrifuged twice, at $2500 \mathrm{~g}$, and $\mathrm{Ni}$ concentration in the supernatant was determined by atomic absorption spectrophotometry. Adsorption isotherms were elaborated for soil samples at natural $\mathrm{pH}$ from the experiments with increasing $\mathrm{Ni}$ concentrations $\left(5.0\right.$ to $\left.80.0 \mathrm{mg} \mathrm{L}^{-1}\right)$, with $\mathrm{Ca}\left(\mathrm{NO}_{3}\right)_{2} 0.01 \mathrm{~mol} \mathrm{~L}^{-1}$ as electrolytic support. Under similar experimental conditions, adsorption envelopes were constructed by the $\% \mathrm{Ni}_{\text {ads }} v s \mathrm{pH}$ plot, after adjusting the $\mathrm{pH}$, by adding $\mathrm{HCl}$ or $\mathrm{NaOH} 4 \mathrm{~mol} \mathrm{~L}^{-1}$, in the suspensions containing 5 $\mathrm{mg} \mathrm{L}^{-1} \mathrm{Ni}$ in $\mathrm{Ca}\left(\mathrm{NO}_{3}\right)_{2} \quad 0.01,0.1$ and $1.0 \mathrm{~mol} \mathrm{~L}^{-1}$ electrolyte support, for the simultaneous verification of the $\mathrm{pH}$ and ionic strength effects on the $\mathrm{Ni}$ adsorption reaction. Previous trials were carried out to verify the volume of $0.04,0.4$ and
$4.0 \mathrm{~mol} \mathrm{~L}^{-1} \mathrm{HCl}$ and $\mathrm{NaOH}$ solutions to be added to reach the desired $\mathrm{pH}$ variation (3.0 to 8.0), so as not to exceed $2 \%$ of the volume of the electrolyte support. All the procedures were performed in triplicate.

The quantity of adsorbed $\mathrm{Ni},[\mathrm{Ni}]_{\mathrm{ads}}$, and the adsorption percentage, $\% \mathrm{Ni}_{\text {ads }}$, were calculated by the ratios:

$$
\begin{aligned}
& {[N i]_{a d s}=\frac{\left([N i]_{0}-[N i]_{e q}\right) V}{M}} \\
& \% N i_{a d s}=\frac{\left([N i]_{0}-[N i]_{e q}\right)}{[N i]_{0}} \times 100
\end{aligned}
$$

where $[\mathrm{Ni}]_{\text {ads }}$ was the quantity of $\mathrm{Ni}$ adsorbed after equilibrium $\left(\mathrm{mg} \mathrm{kg}^{-1}\right) ;[\mathrm{Ni}]_{0}$ and $[\mathrm{Ni}]_{\mathrm{eq}}$ were the added initial and equilibrium concentration $\left(\mathrm{mg} \mathrm{L}^{-1}\right)$, respectively; $\mathrm{V}=$ solution volume $(\mathrm{mL})$; and $\mathrm{M}=$ mass of the soil sample $(\mathrm{g})$. The $\mathrm{Ni}$ quantities originally present in the soil samples were subtracted from the quantity of $\mathrm{Ni}$ adsorbed.

Adsorption isotherms $\left([\mathrm{Ni}]_{\mathrm{ads}}\right.$ vs $\left.[\mathrm{Ni}]_{\mathrm{eq}}\right)$ were constructed from the experimental results, and the $\mathrm{Ni}$ adsorption $\left(\mathrm{Ads}_{\mathrm{eq}}\right.$ ) was compared with that estimated by the nonlinear form of the Langmuir isotherm:

$$
A d s_{e q}=\frac{K_{L} C_{e q} A d s_{\max }}{1+K_{L} C_{e q}}
$$

where $\mathrm{K}_{\mathrm{L}}$ was the parameter related to the soil affinity for $\mathrm{Ni}\left(\mathrm{L} \mathrm{kg}^{-1}\right) ; \mathrm{C}_{\mathrm{eq}}$ was equilibrium concentration; and $\mathrm{Ads}_{\max }$ was the maximum $\mathrm{Ni}$ adsorption capacity $\left.(\mathrm{mg} \mathrm{kg})^{-1}\right)$. The Langmuir isotherm was fitted to the $\mathrm{Ni}$ adsorption results by the Fitfunc and Fitfun.bas softwares (Barrow, 1987), which used the nonlinear optimization of the least squares and did not require the linearization of the isotherm. This procedure avoided the introduction of changes in the error distribution and acquisition of influenced parameters ( $\mathrm{K}_{\mathrm{L}}$ and $\mathrm{Ads}_{\max }$ ) (Goldberg et al., 1993).

\section{Thermodynamic parameters of adsorption reaction}

The contact between the solid phase and the species present in the solution may or may not occur under the equilibrium conditions (Suarez, 1999). In both cases, adsorption reactions can be described mathematically by determining the 
Gibbs free energy (Silveira et al., 1999; Dias et al., 2003; Soares et al., 2005; Casagrande et al., 2008; Mouta et al., 2008; Soares et al., 2009):

$$
\Delta \mathrm{G}=\mathrm{RT}\left(\log \mathrm{C}_{\mathrm{eq}}-\log \mathrm{C}_{0}\right)
$$

where $\Delta \mathrm{G}$ was the variation in the free energy ( $\mathrm{J}$ $\mathrm{mol}^{-1}$ ); $\mathrm{R}$ was the universal constant of the gases $=$ $8.314 \mathrm{~J} \mathrm{~mol}^{-1} \mathrm{~K}^{-1}$; $\mathrm{T}$ was the absolute temperature $(\mathrm{K})$; and $\mathrm{C}_{0}$ was added initial concentration.

The characteristics of the Langmuir isotherm could be expressed in terms of the separation factor or equilibrium parameter, $K_{R}$ a dimensionless constant that indicated whether the adsorption reaction was favorable by the equation (Ho et al., 2002; Mahramanliouglu et al., 2002; Singh and Pant, 2004; Soares et al., 2005; Casagrande et al., 2008; Mouta et al., 2008; Soares et al., 2009):

$$
K_{R}=\frac{1}{1+K_{L} C_{0}}
$$

where $\mathrm{K}_{\mathrm{L}}$ was the affinity constant estimated by the Langmuir equation (Eq. 3).

\section{RESULTS AND DISCUSSION}

\section{Soil attributes}

Table 1 shows some chemical, physical and mineralogical attributes of the soils. Oxisols subsoil samples presented ZPSE values higher than soil $\mathrm{pH}$ and this resulted in a positive equilibrium charge, as confirmed by the $\Delta \mathrm{pH}$ values. In the first $125 \mathrm{~cm}$ of depth, Oxisols also presented effective cation exchange capacity (ECEC) less than $15 \mathrm{mmol}_{\mathrm{c}} \mathrm{kg}^{-1}$ of clay and $\mathrm{pH}_{\mathrm{KCl}}$ $\geq$ 5.0, meeting the requirements for the manifestation of acric properties (Soil Survey Staff, 1999). These soils were close to the end of their pedogenetic development cycle. They had undergone intense desilicatization because of the prolonged weathering action that was reflected by the low $\mathrm{Ki}$ values (Table 1 ). High $\sigma_{\mathrm{H}} / \sigma_{\mathrm{o}}$ ratios showed also the predominance of variable charges in the acric Oxisols. This condition was expected, because the main constituents of the solid phase of these soils were organic matter, kaolinite and the $\mathrm{Fe}$ and $\mathrm{Al}$ (oxy)hydroxides, whose surface charge varied according to the $\mathrm{pH}$ and ionic strength of the system. Rhodic Acrudox presented the highest $\mathrm{Fe}$ and $\mathrm{Al}$ contents extracted by sulfuric acid and by the Na-DCB solution, which corresponded to the contents present in the structure of the secondary minerals and to those regarding the crystalline forms, respectively. Rhodic Acrudox, when compared to Xanthic Acrudox and Rhodic Hapludalf, presented higher and similar contents of poorly crystalline iron oxides, respectively. This fraction corresponded to the more reactive oxide species with greater specific surface.

Table 1 - Chemical, physical and mineralogical attributes of the soils.

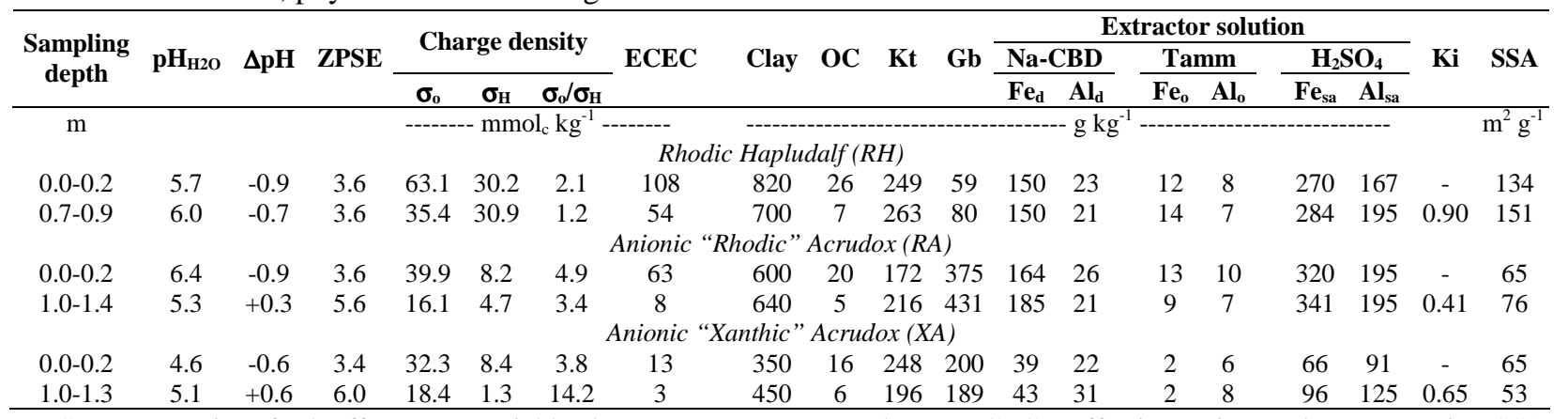

ZPSE = zero point of salt effect; $\sigma_{0}=$ variable charge; $\sigma_{\mathrm{H}}=$ permanent charge; ECEC $=$ effective cation exchange capacity; SSA $=$ specific surface area; $\mathrm{OC}=$ organic carbon; $\mathrm{Kt}=$ Kaolinite; $\mathrm{Gb}=$ gibbsite $; \mathrm{Fe}_{\mathrm{d}}$ and $\mathrm{Al}_{\mathrm{d}}=$ iron and aluminum extracted by sodium citrate-bicarbonate-ditionite (Na-CBD); $\mathrm{Fe}_{\mathrm{o}}$ and $\mathrm{Al}_{\mathrm{o}}=$ iron and aluminum extracted by Tamm's solution $\left[(\mathrm{COOH})_{2} \cdot 2 \mathrm{H}_{2} \mathrm{O}+\left(\mathrm{NH}_{4}\right)_{2} \mathrm{C}_{2} \mathrm{O}_{4} \cdot \mathrm{H}_{2} \mathrm{O}\right] ; \mathrm{Fe}_{\mathrm{as}}$ and $\mathrm{Al}_{\mathrm{as}}=$ iron and aluminum extracted by $\mathrm{H}_{2} \mathrm{SO}_{4} 9 \mathrm{~mol} \mathrm{~L}^{-1} ; \mathrm{Ki}=$ wheathering index $=$ $\mathrm{SiO}_{2} / \mathrm{Al}_{2} \mathrm{O}_{3}$. 
The decrease in the $\sigma_{\mathrm{H}}$ values with depth was attributed to the decrease in organic matter content, the main supplier of variable negative charges in wet tropical soils. In the absence of organic matter, $\mathrm{Fe}$ and $\mathrm{Al}$ (oxy)hydroxides were responsible for maintaining about 50\% of the reversible charges. High permanent and variable charge values were found in $\mathrm{RH}$, which conferred greater charge density. This occurred in consequence of the less advanced weathering stage of $\mathrm{RH}$, whose $\mathrm{Ki}$ value indicated less intense silica loss, justifying both its greater kaolinite contents and the occurrence of clay minerals of the 2:1 type [interstratified chloride/vermicullite and vermicullite (results not shown)], responsible not only for the manifestation of permanent charges $\left(\sigma_{\mathrm{H}}\right)$ but also for the increase in the specific surface area (SSA). Gibbsite contents were particularly high in the Oxisols, and the occurrence of this mineral has implications on the magnitude of the electric charges, especially in the deeper horizons, where the $\mathrm{CO}$ contents were small. Regarding the clay fraction of the soils, Rhodic Acrudox, because it was the most weathered, presented greater crystalline $\left(\mathrm{Fe}_{\mathrm{d}}\right)$ and amorphous $\left(\mathrm{Fe}_{\mathrm{o}}\right) \mathrm{Fe}$ oxide contents, followed by the Alfisol.

\section{Adsorption isotherms at natural pH}

Figure 1 shows the typical $\mathrm{Ni}$ adsorption isotherms by the weathered soils at natural $\mathrm{pH}$ and constant $0.01 \mathrm{~mol} \mathrm{~L}^{-1} \mathrm{Ca}\left(\mathrm{NO}_{3}\right)_{2}$ ionic strength. Nickel adsorption increased as more concentrated solutions of the metal were added (Fig. 1).
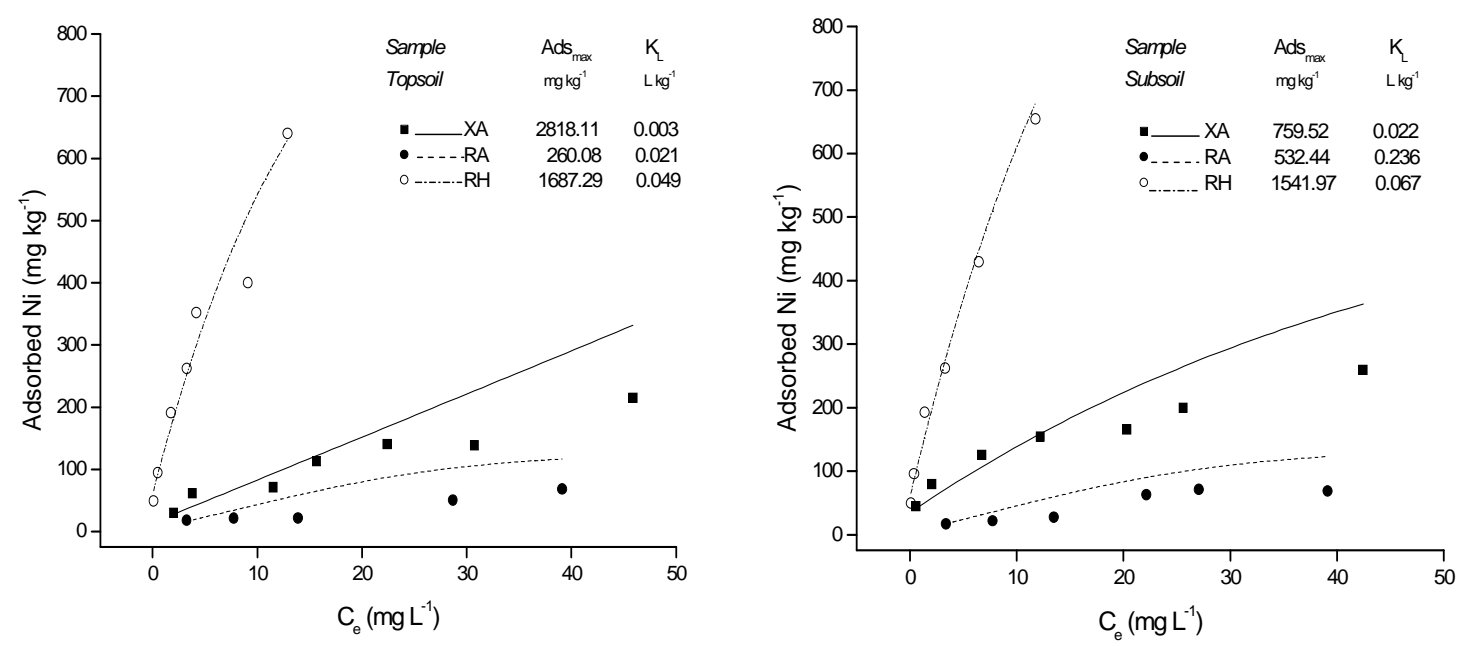

Figure 1 - Isotherms and parameters of nickel adsorption $\left(\mathrm{Ads}_{\max }=\right.$ maximum adsorption; $\mathrm{K}_{\mathrm{L}}=$ affinity constant) obtained from the adjustment of the Langmuir equation (curves) to the experimental results (points); XA = Anionic "Xanthic" Acrudox; RA= Anionic "Rhodic" Acrudox; RH = Rhodic Hapludalf.

Adsorption curve slope obtained for RH indicated the more expressive increase in adsorption at lower $\mathrm{Ni}$ concentrations initially added. Isotherms fitted to the Oxisols, regardless of depth, were Ctype, characterized by a small initial slope which remained constant and was not related to the equilibrium concentration (Sposito, 1989). The high initial slope in the H-type isotherms shown by $\mathrm{RH}$ suggested high affinity of the soil for $\mathrm{Ni}$, as a result of inner-sphere type surface complexing mechanisms, or to significant adsorption processes mediated by van der Waals interactions (Sposito,
1989), or to the predominance of hydrolyzed metallic species (James and Healy, 1972; Echeverría et al., 2003).

Langmuir equation, whose original derivation considered only the forces involved between the adsorbate and the adsorbent surface, leading to the formation of a monolayer of metal over the active sites of a homogeneous surface, simulated adequately the experimental results of $\mathrm{Ni}$ adsorption (Fig. 1).

Thus, Langmuir model could be used to prognosticate $\mathrm{Ni}$ performance in the soils with 
attributes similar to those in this study (Table 1). Experimental results obtained for $\mathrm{RH}$ showed higher adherence to the Langmuir isotherm compared to those of the Oxisols, which showed small deviations between the observed and simulated results with the increase in the $\mathrm{Ni}$ concentrations added (Fig. 1). The appropriate fit of the $\mathrm{Ni}$ adsorption results by Oxisols, and even by less weathered soils to the Langmuir isotherm had been reported previously (Camargo et al., 1989; Pombo et al., 1989). The parameters derived from the isotherms fit were convenient for comparative assessment of different soils and elements. The adsorption parameters, $\mathrm{Ads}_{\max }$ and $\mathrm{K}_{\mathrm{L}}$, indicated that $\mathrm{Ni}$ adsorption varied according to the soil and sampling depth (Fig. 1). Practically in all the cases, isotherms did not become asymptotic and the maximum adsorption was estimated by the fit of the least squares of the Langmuir equation. The $\mathrm{Ni} \mathrm{Ads}_{\max }$ ranged from 260 (RA) to $2818 \mathrm{mg} \mathrm{kg}^{-1}$ (XA) in the topsoil layer. This more than tenfold variation was associated to the soil type, especially to the mineralogy. The soils with similar $\mathrm{Fe}$ (oxy)hydroxide contents may differ appreciably in their ability to retain heavy metals. Xanthic Acrudox had lower clay and free iron oxide contents (Table 1), but because of its coloring, its mineralogical composition was probably dominated by goethite. Iron oxides such as hematite $\left(\alpha-\mathrm{FeO}_{3}\right)$ have two thirds of their octahedric sites filled, while hydrated oxides, such as goethite $(\alpha-\mathrm{FeOOH})$, had only half their octahedric sites filled (Cornell and Schwertmann, 1996). This mean higher density of hydroxylic surface sites available for adsorption. In the subsoil, RH presented the highest $\mathrm{Ni}$ adsorption capacity (1541 mg kg${ }^{-1}$ ) and maintained practically the same capacity shown by the topsoil sample. This result indicated that organic matter could not have such a decisive effect on $\mathrm{Ni}$ adsorption by $\mathrm{RH}$, since this soil still had permanent charge sites $\left(\sigma_{\mathrm{H}}\right)$ for adsorption as a result of its less advanced weathering condition (see $\mathrm{Ki}$ in Table 1). On the other hand, higher Ads $\mathrm{max}_{\max }$ values were detected in the samples from the Oxisols topsoil horizons and should be correlated with the organic carbon content, ratifying results of other studies with metal adsorption by highly weathered soils (Silveira and Alleoni, 2003; Casagrande et al., 2008; Mouta et al., 2008; Soares et al., 2009). Mellis et al. (2004) reported decrease in $\mathrm{Ni}$ adsorption after eliminating the organic matter in the weathered soils. According to Soares and Alleoni (2008), soil organic matter was responsible for 50 to $95 \%$ of the cation exchange capacity (CEC) in Brazilian Oxisols, whose inorganic fraction was composed by low reactive minerals. The authors estimated that the contribution of organic matter to soil CEC was more than 60 times higher than the one of clay fraction. Although organic matter favors the adsorption of a greater quantity of $\mathrm{Ni}, \mathrm{K}_{\mathrm{L}}$ constants estimated by the Langmuir model (Fig. 1), which represents the combined effect of all the reactions that occurred on the solid/liquid interface (Angove et al., 1999), suggested that $\mathrm{Ni}$ was more strongly adsorbed in the subsoil horizons.

In this soil layer, the organic matter has less influence and permits higher exposure of the mineral colloid surfaces that are hidden in the topsoil layers because of the direct association between $\mathrm{Fe}$ and $\mathrm{Al}$ (oxy)hydroxides, gibbsite and kaolinite with organic compounds.

\section{Adsorption envelopes: influence of soil $\mathrm{pH}$ on Ni adsorption}

There is a critical $\mathrm{pH}$ interval for the solid/solution interfaces, generally smaller than two units, where the metal adsorption percentage may increase sharply from extremely low $\mathrm{pH}$ value to $100 \%$ at high $\mathrm{pH}$ values (Sposito, 1989; Soares and Casagrande, 2009). This critical interval, known as the adsorption edge, is related to the hydrolysis constant of the metallic ion. The degree to which the metals are hydrolyzed is probably the main factor that determines the quantity of metal retained at a given $\mathrm{pH}$ (James and Healy, 1972; Harter, 1983). Adsorption envelopes (Fig. 2), represented graphically by $\%$ ads $v s \mathrm{pH}$ plot, showed the relative proportion of $\mathrm{Ni}$ removal from the solution, for a constant ionic strength of $0.01 \mathrm{~mol} \mathrm{~L}^{-1} \mathrm{Ca}\left(\mathrm{NO}_{3}\right)_{2}$ and at fixed initial concentration of $5 \mathrm{mg} \mathrm{L}^{-1}$ of $\mathrm{Ni}$. 

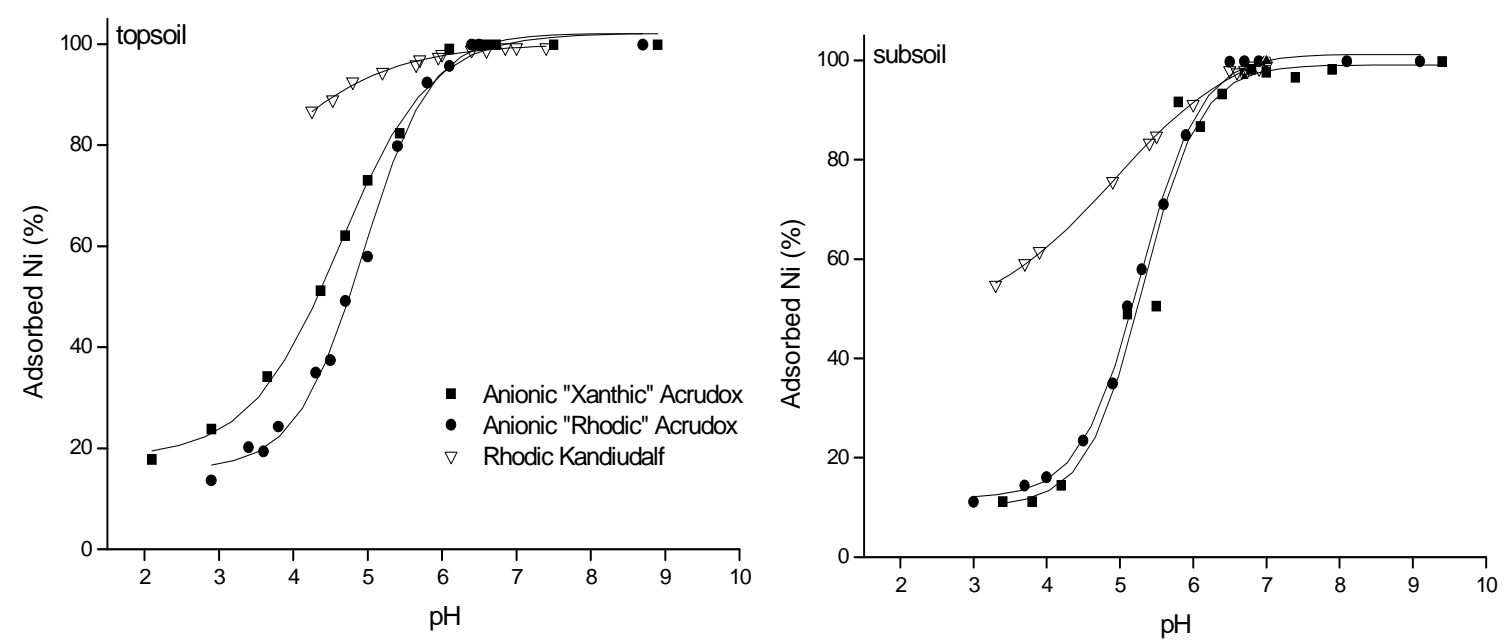

Figure 2 - Nickel adsorption envelopes for topsoil and subsoil samples from highly weathered tropical soils after addition of $5 \mathrm{mg} \mathrm{L}^{-1} \mathrm{Ni}$.

Nickel adsorption depended greatly on the $\mathrm{pH}$, regardless of soil or sampling depth, and increased sharply with the increase in $\mathrm{pH}$ from 4.0 to 6.0 , an interval when $20-90 \% \mathrm{Ni}$ adsorption occurred (Fig. 2). Many adsorption studies with mineral soils have shown increase in $\mathrm{Ni}$ adsorption with increase in $\mathrm{pH}$ (Harter, 1983; Elzinga and Sparks, 2001). Harter (1983) and Beukes et al. (2000) reported that metal adsorption was $\mathrm{pH}$-dependent and that the intensity of the phenomenon increased drastically above $\mathrm{pH}$ 7.0. Practically all the Ni added $\left(5 \mathrm{mg} \mathrm{L}^{-1}\right)$ disappeared from the soil solution when the $\mathrm{pH}$ was over 7.0, regardless of soil or sampling depth. This occurred at high $\mathrm{pH}$ values because the $\mathrm{Ni} \mathrm{pKa} \mathrm{a}_{1}$ was around 9.6, above the $\mathrm{pKa}_{1}$ values for other metals such as $\mathrm{Pb}, \mathrm{Cu}$ and $\mathrm{Zn}$ (Mellis et al., 2004). Thus, even at the highest $\mathrm{pH}$ values reached in this study, the possibility of the presence of $\mathrm{Ni}(\mathrm{OH})_{2}{ }^{0}$ was very small (James and Healy, 1972). Even so, rapid increase in $\mathrm{Ni}$ adsorption above $\mathrm{pH} 8.0$ may also be associated to the start of the hydroxide precipitation reactions with the $\mathrm{Ni}^{2+}$ and $\mathrm{NiOH}^{+}$ species (Sen Gupta and Bhattacharyya, 2006). It is expected that $\mathrm{Ni}\left(\mathrm{H}_{2} \mathrm{O}\right)_{6}{ }^{2+}$ form be found at low $\mathrm{pH}$ values and that the complexes with $\mathrm{OH}^{-}$and organic ligands start to predominate as the $\mathrm{pH}$ increases (Uren, 1992).

The proportion of adsorbed metallic ions increased uniformly and continually with the increase in $\mathrm{pH}$, but the shape of the curve and its position depended on the soil identity, especially regarding its mineralogical constitution (Fig. 2). The adsorption pattern was very similar for the Oxisols samples, as the shape and positioning of the adsorption edges showed, even as overlapping in the cases of the subsoil Oxisols samples (Fig. 2). The adsorption edges for $\mathrm{Ni}$ adsorption by the Oxisols presented the typical sigmoidal shape, mainly in relation to their positioning (Fig. 2). In these soils, Ni retention was characterized initially by a small slope at the $2.0-3.5 \mathrm{pH}$ range, where about $25 \%$ of the $\mathrm{Ni}$ added to the topsoil samples was adsorbed, and 3.0-4-5 in the samples collected in the subsoil, where approximately $15-20 \%$ of $\mathrm{Ni}$ was removed from the solution (Fig. 2). Harter (1983) observed similar gentle initial slope for $\mathrm{Cu}$ and $\mathrm{Zn}$ adsorption curve in an Alfisol, which was attributed to the intense competition between the metal and the $\mathrm{H}^{+}$and $\mathrm{Al}^{3+}$ ions for exchange sites. According to the author, the slope of the adsorption curve tended to increase as the $\mathrm{Al}^{3+}$ was removed from the exchange complex by hydrolysis reaction, which was enhanced with increasing $\mathrm{pH}$.

Atypical shape of the adsorption edge for Rhodic Hapludalf suggested that $\mathrm{Ni}$ adsorption was qualitatively different when compared with the Oxisols. For a given type of adsorption surface, adsorption edge is a function of the affinity and normally it is argued that this affinity is high when adsorption occurs at low $\mathrm{pH}$ values, as detected for Rhodic Hapludalf (Fig. 2). This soil adsorbed more than $80 \%$ of the $\mathrm{Ni}$ at $\mathrm{pH} 4.5$ and $50 \%$ at $\mathrm{pH}$ 3.5 , on the topsoil and subsoil, respectively. High quantity of $\mathrm{Ni}$ was fastly adsorbed in the first $\mathrm{pH}$ values of the Rhodic Hapludalf samples, probably as a result of the manifestation of permanent 
charges $\left(\sigma_{\mathrm{H}}\right)$, which did not depend on the $\mathrm{pH}$ variation (Table 1). Results from envelopes suggested that soil $\mathrm{pH}$ management was a promising, efficient and cheap technique as a remediation action in areas contaminated by $\mathrm{Ni}$.

\section{Thermodynamic parameters of $\mathrm{Ni}$ adsorption reaction}

\section{Separation factor $\left(K_{R}\right)$}

Preliminary information regarding the degree of development and spontaneity of the adsorption reaction could be obtained from assessing the equilibrium parameter or the $K_{R}$ separation factor (Eq. 5), calculated from the $\mathrm{K}_{\mathrm{L}}$ Langmuir constant (Eq. 3). Following a more simplified approach, adsorption is favorable and spontaneous when $K_{R}$ $<1$, while values of $K_{R}>1$ indicate the absence of spontaneity in the reaction (Mahramanliouglu et al., 2002; Singh and Pant, 2004; Soares et al., 2005). The $K_{R}$ coefficient can further indicate whether the adsorption isotherm is unfavorable to the process $\left(K_{R}>1\right)$, linear $\left(K_{R}=1\right)$, favorable $(0$ $\left.<K_{R}<1\right)$ or irreversible $\left(K_{R}=0\right)$ (Ho et al., 2002). The $K_{R}$ values for $\mathrm{Ni}$ adsorption reaction decreased with the increase in the initial $\mathrm{Ni}$ concentration and were always higher than 1 (Fig. 3 ), confirming some results obtained for metallic cation reactions (Ho et al., 2002; Casagrande et al., 2008). This indicated that the adsorption reaction was more favorable and spontaneous for high initial $\mathrm{Ni}$ concentrations, further showing that all the soils were good systems for $\mathrm{Ni}$ retention, ranking RH > RA > XA (Fig. 3). Except for XA, for the other soils the separation factor was a parameter not very sensitive to the depth. For XA, the $K_{R}$ values were lower for the subsoil samples, indicating that $\mathrm{Ni}$ adsorption developed more spontaneously in the absence of organic matter and validating the indications of the affinity constant $\mathrm{K}_{\mathrm{L}}$ (Fig. 1).

The $K_{R}$ parameter was sensitive to the ion hydrated radii (Soares et al., 2005) and under the conditions in which the adsorption experiments for isotherm construction were developed, that is, at the natural $\mathrm{pH}$ of the samples ( $\mathrm{pH}$ between 4.0 and 5.5), higher $K_{R}$ values were expected, because the hydrated ions of hexaquonickel $\left[\mathrm{Ni}\left(\mathrm{H}_{2} \mathrm{O}\right)_{6}{ }^{2+}\right]$ was the most stable form and most found in soil solution at low pH values (Bowman et al., 1981; Uren, 1992).
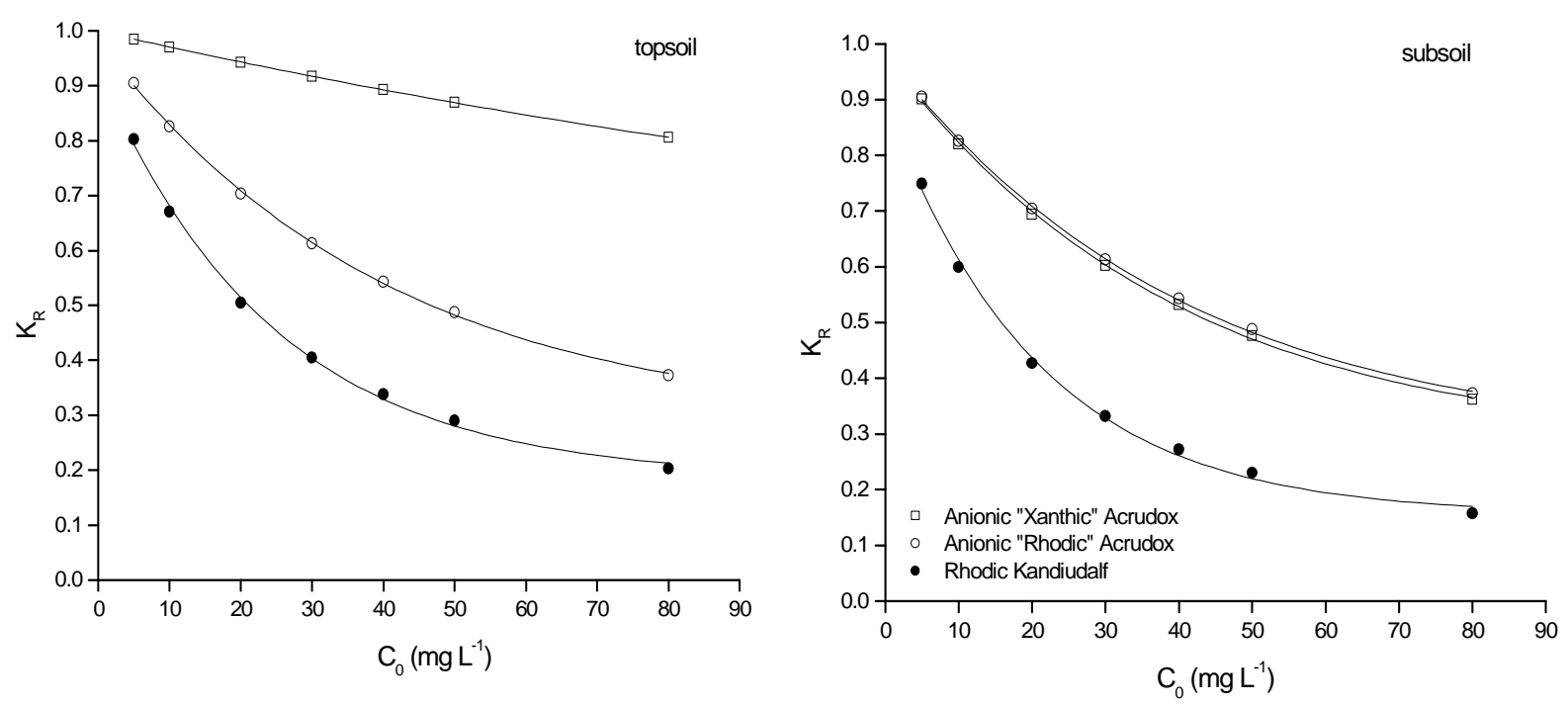

Figure 3 - Separation factor $\left(\mathrm{K}_{\mathrm{R}}\right)$, at natural $\mathrm{pH}$, as affected by initial concentration of $\mathrm{Ni}\left(\mathrm{C}_{0}\right)$; XA = Anionic "Xanthic" Acrudox; RA = Anionic "Rhodic" Acrudox; RH = Rhodic Hapludalf. 
These two factors were arguments to consider the occurrence of specific Ni adsorption mechanisms, because inner-sphere type complex formation did not permit the interposition of water molecules on the solid/solution interface and justifies the adsorption of ions with smaller hydrated radii, quantitatively characterized by low $\mathrm{K}_{\mathrm{R}}$ values (Fig. 3).

\section{Free energy variation in Ni adsorption $(\Delta \mathbf{G})$}

Nickel adsorption was reflected by the values of the variation in free energy $(\Delta \mathrm{G})$, whose negative sign indicated the exergonic nature of the reaction, with energy release for conversion of the less stable Ni forms in solution in adsorbed forms with greater stability. The adsorption reaction of metallic elements by the organic and inorganic surfaces of pure or isolated systems is usually spontaneous. The spontaneity of the $\mathrm{Cd}$ (Dias et al., 2003; Soares et al., 2009), Cu (Silveira et al., 1999; Mouta et al., 2008), Ni (Iglesias et al., 2007), and Zn (Casagrande et al., 2008) adsorption reaction by weathered soils was also characterized by negative free energy values.

Negative $\Delta G$ values (Fig. 4) were in line with $K_{R}$ values (Fig. 3) and confirmed the feasibility and spontaneous nature of $\mathrm{Ni}$ adsorption reaction. When increased element content added to the soil is considered, $\Delta \mathrm{G}$ value may reveal the magnitude of the extension of the reaction between the element and the adsorption surface (Soares et al., 2005, Mouta et al., 2008; Soares and Casagrande, 2009). Thus, negative $\Delta \mathrm{G}$ values imply that the reaction must be occurring in the direction of product formation, that is, in the direction of adsorption occurrence. The more negative the $\Delta \mathrm{G}$ values, the greater the motrice force needed for adsorption to occur.

The $\Delta \mathrm{G}$ values decreased with the increase in the quantity of $\mathrm{Ni}$ added. The decrease in the free energy of the $\mathrm{Cu}$ (Silveira et al., 1999), Cd (Dias et al., 2003), Ni (Iglesias et al., 2007) and B (Soares et al., 2005) adsorption reaction by highly weathered soils with the increase in the concentration led to the conclusion that the elements were less strongly adsorbed in more concentrated solutions, contrary to that shown by the separation factor $\left(K_{R}\right)$ (Fig. 3). As C-type isotherm showed (Fig. 1), lower concentrations added initially might not have been able to saturate the adsorption sites. However, $\Delta \mathrm{G}$ values were negative for all the concentration range and, in addition to the spontaneity of the reaction, this again indicated that the sorbed forms were more stable than those in solution (Soares et al., 2009). When compared under the standard $0.01 \mathrm{~mol} \mathrm{~L}^{-1}$ ionic strength condition, which best reproduced the natural conditions of the soil solution, the maximum $\Delta \mathrm{G}$ values was $-4850 \mathrm{~J} \mathrm{~mol}^{-1}$ for subsoil sample from $\mathrm{RH}$ at $\mathrm{pH}$ 7.0. The maximum $\Delta \mathrm{G}$ values for the acric oxisol samples did not vary with depth and occurred at $6.0 \mathrm{pH}$. Oxisols presented higher $\Delta \mathrm{G}$ values than the Alfisol, and indicated that $\mathrm{Ni}$ adsorption was more favored in the more weathered soils.

Figure 4 illustrates the influence of the $\mathrm{pH}$ on the spontaneity of adsorption reaction after adding 5 $\mathrm{mg} \mathrm{L}^{-1}$ og Ni. In all the samples, $\Delta \mathrm{G}$ increased with the increase in the $\mathrm{pH}$, showing not only that $\mathrm{Ni}$ adsorption increased with the increase in $\mathrm{pH}$ (Fig. 2), but also that the reaction was favored by the decrease in the hydrogen ion concentration. In summary, as the $\mathrm{pH}$ increased, $\Delta \mathrm{G}$ became more negative as the result of the increase in the motrice force needed for adsorption reaction.

\section{Influence of soil solution ionic strength (I) on $\mathrm{Ni}$ adsorption}

Nickel adsorption was also assessed regarding the alterations in the electrolyte support concentration, using $\Delta \mathrm{G}$ as numerical parameter of the reaction (Fig. 4). The dependency of metal adsorption in relation to the ionic strength also gave indications of outer- or inner-sphere complex formation with colloid surface (Petruzzelli et al., 1985; Criscenti and Sverjensky, 1999). The lack of dependence of metal adsorption on the ionic strength gives an indication of complexing by inner-sphere mechanisms, typical of transition metallic elements. This occurred in a particular form in the Oxisols samples and in the lower $\mathrm{pH}$ value range (3-5). In this situation, the $\mathrm{pH}$ value was much below the zero point of salt effect (ZPSE) of the predominant mineralogical constituents of the Oxisols, especially hematite, goethite and amorphous (oxy)hydroxides (Beukes et al., 2000). Metallic ion adsorption by positively charged surfaces is insensitive to the alterations in the ionic strength (Kosmulski, 1997). 

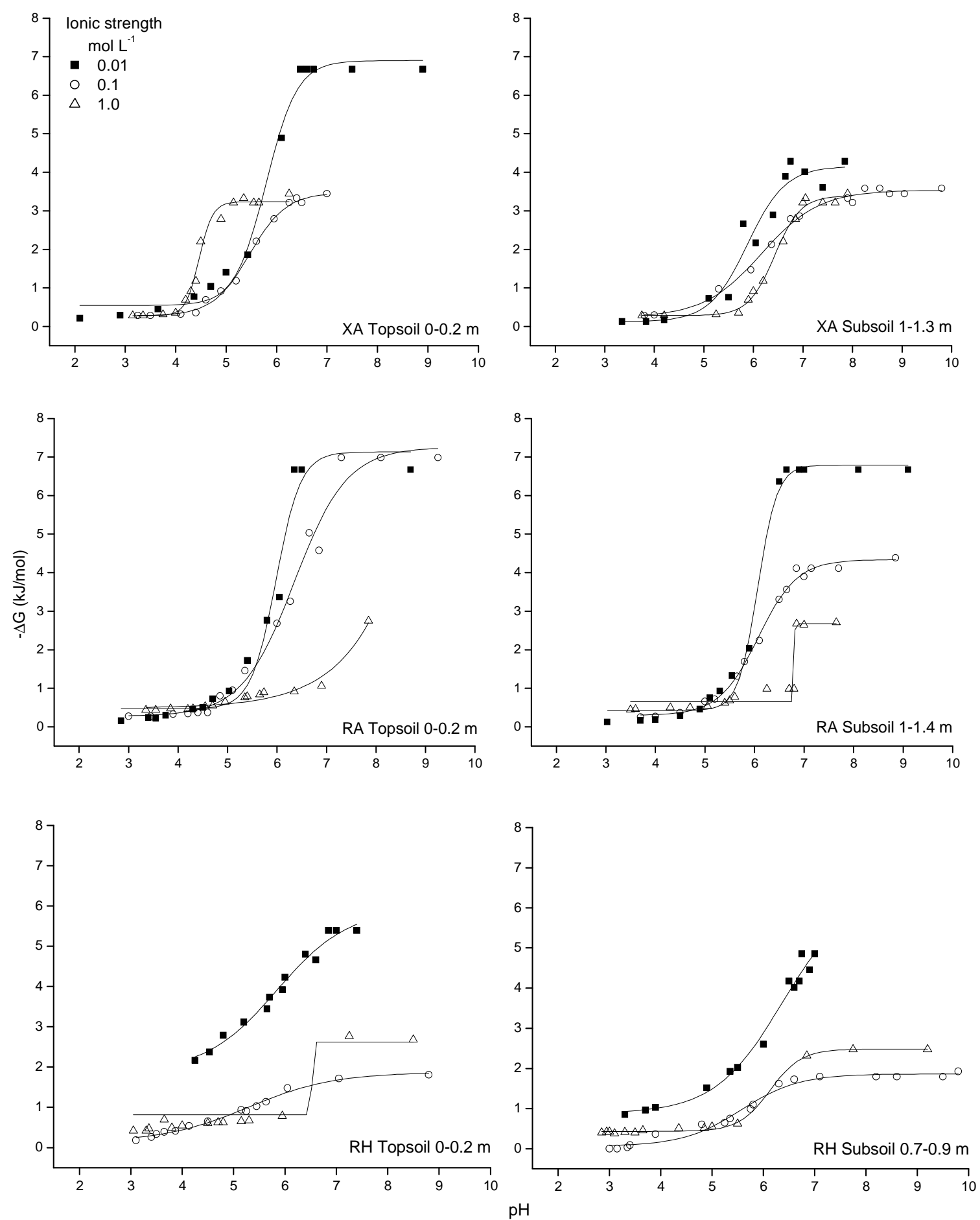

Figure 4 - Effect of soil solution parameters ( $\mathrm{pH}$ and ionic strength) on free energy of $\mathrm{Ni}$ adsorption reaction by highly weathered soils; XA = Anionic "Xanthic" Acrudox; RA = Anionic "Rhodic" Acrudox; RH = Rhodic Hapludalf. 
Starting at $\mathrm{pH}$ 5.0, higher dependence of $\mathrm{Ni}$ adsorption was identified in relation to the ionic strength in the Oxisols (Fig. 4), which implied the manifestation of nonspecific adsorption mechanisms under these conditions. Although the essential mechanism for metal adsorption by $\mathrm{Fe}$, $\mathrm{Al}$ and $\mathrm{Mn}$ (oxy)hydroxides is specific and $\mathrm{pH}$ dependent, increasing with the $\mathrm{pH}$, heavy metals can be adsorbed by the electrostatic attraction in the diffuse double layer by ion exchange (Mesquita and Vieira e Silva, 2002). According to Uren (1992), $\mathrm{Ni}$ adsorption in the soils is particularly governed by the formation of outersphere type complexes and, because of this, $\mathrm{Ni}$ cation species $\left(\mathrm{Ni}^{2+} \mathrm{e} \mathrm{NiOH}^{+}\right)$are the preferential adsorbed forms.

The intensity of the effect of the ionic strength on specific metallic cation adsorption depends greatly on the surface charge signal and on the determined $\mathrm{pH}$ (Kosmulski, 1997). For the Alfisol, the adsorption dependence on the ionic strength was observed throughout the $\mathrm{pH}$ range (Fig. 4), because the manifestation of electrostatic adsorption mechanisms did not depend on the $\mathrm{pH}$, due to the higher quantity of permanent charges (Table 1). Considering the simultaneous effect of the $\mathrm{pH}$ and ionic strength on $\mathrm{Ni}$ adsorption, Scheidegger et al. (1996) differentiated two $\mathrm{pH}$ levels more sensitive to the changes in the electrolytic concentration of the solution. The authors observed that in the region with lower $\mathrm{pH}$ values, that is, below neutrality, $\mathrm{Ni}$ adsorption increased with the decrease in the ionic strength, while at the values of $\mathrm{pH}>7.0, \mathrm{Ni}$ adsorption seemed to have been affected by the ionic strength. Contrary to the $\mathrm{pH}$, the increase in ionic strength decreased the intensity and spontaneity of the $\mathrm{Ni}$ adsorption reaction, because the $\Delta \mathrm{G}$ values decreased sharply when the support electrolyte concentration increased ten fold and one hundred fold (Fig. 4). Echeverría et al. (2003) reported the same effect for $\mathrm{Ni}$ adsorption by illite. The decrease in metallic ion adsorption with the increase in the ionic strength are attributed to: (i) the type of metal; (ii) changes in the free ion activity and $\mathrm{MOH}^{+}$species; (iii) the type of surface, surface charge effect and alterations in the electrostatic potential on the adsorption plane and; (iv) the increase in competition for adsorption sites among the cation index and the metallic ions (Boekhold et al., 1993; Naidu et al., 1997; Criscenty and Sverjensky, 1999).
For practical purposes, the increase in the soil solution ionic strength by the excessive discharge of residues and effluents may cause increase in $\mathrm{Ni}$ mobility in the soil, especially if the pollutant contains competitive cations in its composition. In these cases of high $\mathrm{Ni}$ polluting charge, the increase in $\mathrm{Ni}$ mobility by the high eletrolytic concentration of the solution might be reduced again by the rise in $\mathrm{pH}$ (Fig. 4).

The $\mathrm{Ni}^{2+}$ cation is known to form complexes with various organic and inorganic ligands (Bowman et al., 1981). Many studies have considered the effect of cations and anions that constitute the electrolyte support on metal adsorption, principally regarding to the competitive effect of $\mathrm{Ca}^{2+}$ for adsorption sites and by the action of $\mathrm{Cl}^{-}$in the formation of chloride complexes with less affinity for the surface (Mattigod et al., 1979; Bowman et al., 1981; Wang et al., 1997; Echeverría et al., 2003). Considering the nature of electrolyte support, the effect of the competition between $\mathrm{Ca}^{2+}$ and $\mathrm{Ni}^{2+}$ for the same adsorption sites probably justified the decrease in $\mathrm{Ni}$ adsorption with the increase in ionic strength, rather than the probable formation of complexes between $\mathrm{Ni}$ and the anion because $\mathrm{NO}_{3}{ }^{-}$has much less affinity than $\mathrm{Cl}^{-}$for this type of reaction in solution (Criscenty and Sverjensky, 1999). Boekhold et al. (1993) observed that the competition with the $\mathrm{Ca}$ of the electrolytic support for adsorption sites reduced $\mathrm{Cd}$ adsorption by about $80 \%$ in an acid soil. In practice, this increase of ionic strength in the soil solution may be caused by the excessive discharge of residues and effluents, especially if the pollutant contains competitive cations in its composition (Soares et al., 2009). Tamanini et al. (2008) observed a linear increase between total $\mathrm{Ca}$ and sewage sludge application rate due to rapid release of calcium hydroxide.

Specific adsorption mechanisms are usually accompanied by $\mathrm{H}^{+}$ion release to the soil solution, as a result of their displacement so that the linking of high energy occurs between the surface and the metallic ions. The small alteration in the $\mathrm{pH}$ of the final adsorption extract (data not shown) could be an indication that specific adsorption took place less frequently. Mesquita and Vieira e Silva (2002) reported that the equilibrium solution $\mathrm{pH}$ after $\mathrm{Cu}$ and $\mathrm{Zn}$ adsorption decreased as the concentration of the metals in the initial solutions increased, due to hydrolysis of the metals and release of protons during adsorption. If it is accepted that electrostatic attraction is the predominant 
mechanism, it seems reasonable to accept the hypothesis that, in the case of $\mathrm{Ni}$ adsorption, the effect of the $\mathrm{pH}$ is more critical in determining the adsorbent surface charge and not the metal species in solution due to their action in hydrolysis. Positive charges of the $\mathrm{Ni}$ ions are less repulsed when the $\mathrm{pH}$ reaches values close to the zero point of salt effect of oxide minerals such as goethite (8.5) and hematite (9.2) (Beukes et al., 2000).

As general concluding remarks, chemical and mineralogical soil attributes should always be considered as criteria for selecting the areas for disposal or application of residues containing $\mathrm{Ni}$ to minimize soil contamination and impact on the environment.

\section{ACKNOWLEDGMENTS}

This work was supported by grants from FAPESP (process n. 04/00445-3)

\section{REFERENCES}

Alleoni, L.R.F., Camargo, O.A. (1994), Pontos de efeito salino nulo de latossolos ácricos. Rev. Bras. Cienc. Solo, 18, 175-180.

Angove, M.J., Wells, J.D., Johnson, B.B. (1999), The influence of temperature on the adsorption of cadmium (II) and cobalt (II) on goethite. J. Colloid Interf. Sci., 211, 281-290.

Barrow, N.J. (1987), Reactions with variable-charge soils. Martinus Nijhoff Publishers, Dordrecth.

Basta, N.T., Ryan, J.A., Chaney, R.L. (2005), Trace elements chemistry in residual-treated soil: key concepts and metal bioavailability. J. Environ. Qual., 34, 49-63.

Beukes, J.P., Giesekke, E.W., Elliot, W. (2000), Nickel retention by goethite and hematite. Miner. Eng., 13, 1573-1579.

Boekhold, A.E., Temminghoff, E.J.M., Van der Zee, S.E.A.T.M. (1993), Influence of electrolyte composition and $\mathrm{pH}$ on cadmium sorption by an acid sandy soil. J. Soil Sci., 44, 85-96.

Bowman, R.S., Essington, M.E., O’Connor, G.A. (1981), Soil sorption of nickel: influence of solution composition. Soil Sci. Soc. Am. J., 45, 860-865.
Camargo, O.A., Moniz, A.C., Jorge, J.A., Valadares, J.M.A.S. (1986), Métodos de análise química, mineralógica e física de solos do Instituto Agronômico de Campinas. Instituto Agronômico de Campinas, Boletim Técnico n.106, Campinas.

Camargo, O.A., Rovers, H., Valadares, J.M.A.S. (1989), Adsorção de níquel em Latossolos paulistas. Rev. Bras. Cienc. Solo, 13, 125-129.

Casagrande, J.C., Soares, M.R., Mouta, E.R., (2008), Zinc adsorption in highly weathered soils. Pesqui. Agropecu. Bras., 43, 131-139.

Cornell, R.M., Schwertmann, U. (1996), The iron oxides: structure, properties, reactions, occurrences and uses. VHC, Weinheim.

Criscenti, L.J., Sverjensky, D.A. (1999), The role of electrolyte anions $\left(\mathrm{ClO}_{4}^{-}, \mathrm{NO}_{3}^{-}\right.$, and $\left.\mathrm{Cl}^{-}\right)$in divalent metal $\left(\mathrm{M}^{2+}\right)$ adsorption on oxide and hydroxide surfaces in salt solutions. Am. J. Sci., 299, 828-899.

Davies, J.A., Leckie, J.O. (1978), Effect of adsorbed complexing ligands on trace metals uptake by hydrous oxides. Environ. Sci. Technol., 12, 13091315.

Denkhaus, E., Salnikow, K. (2002), Nickel essenciality, toxicity, and carcinogenicity. Crit. Rev. Oncol. Hemat., 42, 35-56.

Dias, N.M.P., Alleoni, L.R.F., Casagrande, J.C., Camargo, O.A. (2003), Energia livre da adsorção de cádmio em latossolos ácricos. Cienc. Rural, 33, 829834.

Echeverría, J., Indurain, J., Churio, E., Garrido, J. (2003), Simultaneous effect of $\mathrm{pH}$, temperature, ionic strength, and initial concentration on the retention of Ni on illite. Colloid Surface A, 218, 175-187.

Elzinga, E.J., Sparks, D.L. (2001), Reaction condition effects on nickel sorption mechanisms in illite-water suspensions. Soil Sci. Soc. Am. J., 65, 94-101.

Eskew, D.L., Welch, R.M., Cary, E.E. (1983), Nickel: an essential micronutrient for legumes and possibly all higher plants. Science, 222, 621-623.

Feller, C., Schouller, E., Thomas, F., Rouiller, J., Herbillon, A.J. (1992), $\mathrm{N}_{2}$-BET specific surface-areas of some low activity clay soils and their relationships with secondary constituents and organic-matter contents. Soil Sci., 153:293-299.

Goldberg, S., Forster, H.S., Heick, E.L. (1993), Boron adsorption mechanisms on oxides, clay-minerals, and soils inferred from ionic-strength effects. Soil Sci. Soc. Am. J., 57, 704-708.

Harter, R.D. (1983), Effect of soil pH on adsorption of lead, copper, zinc, and nickel. Soil Sci. Soc. Am. J., 47, 47-51. 
Ho, Y.S., Huang, C.T., Huang, H.W. (2002), Equilibrium sorption isotherm for metal ions on tree fern. Process Biochem., 37, 1421-1430.

Iglesias, C.S.M., Casagrande, J.C., Alleoni, L.R. (2007), Efeito da natureza do eletrólito e da força iônica na energia livre da reação de adsorção de níquel em solos. Rev. Bras. Cienc. Solo, 31, 897-903.

James, R.O., Healy, T.W. (1972), Adsorption of hydrolysable metal ions at the oxide-water interface. III. A thermodynamic model of adsorption. J. Colloid Interf. Sci., 40, 65-81.

Kosmulski, M. (1997), The effect of the ionic strength on the adsorption isotherms of nickel on silica. $J$. Colloid Interf. Sci., 190, 212-223.

Mahramanliouglu, M.; Kizilcikli, I.; Bicer, I.O. (2002), Adsorption of fluoride aqueous solution by acid treated spent bleaching earth. J. Fluorine Chem., 115, 41-47.

Mattigod, S.V., Gibali, A.S., Page, A.L. (1979), Effect of ionic strength and ion-pair formation on the adsorption of nickel by kaolinite. Clay. Clay Miner., 27, 411-416.

McKenzie, R.M. (1980), Adsorption of lead and other heavy-metals on oxides of manganese and iron. Aust. J. Soil Res., 18, 61-73.

Mekaru, T., Uehara, G. (1972), Anion adsorption in ferrugineous tropical soils. Soil Sci. Soc. Am. Pro., 36, 296-300.

Mellis, E.V., Cruz, M.C.P., Casagrande, J.C. (2004), Nickel adsorption by soils in relation to $\mathrm{pH}$, organic matter, and iron oxides. Sci. Agric. (Piracicaba, Braz.), 61, 190-195.

Mesquita, M.E., Vieira e Silva, J.M. (2002), Preliminary study of $\mathrm{pH}$ effect in the application of Langmuir and Freundlich isotherms to $\mathrm{Cu}-\mathrm{Zn}$ competitive adsorption. Geoderma, 106, 219-234.

Morera, M.T., Echeverría, J.C., Mazkiarán, C., Garrido, J.J. (2001), Isotherms and sequential extraction procedures for evaluating sorption and distribution of heavy metals in soils. Environ. Pollut., 113, 135-144.

Mouta, E.R., Soares, M.R., Casagrande, J.C. (2008), Copper adsorption as a function of solutions parameters of variable charge soils. J. Brazil. Chem. Soc., 19, 996-1009.

Naidu, R., Kookana, R.S., Sumner, M.E. (1997), Cadmium sorption and transport in variable charge soils: A review. J. Environ. Qual., 26, 602-617.

Petruzzelli, G., Guidi, G., Lubrano, L. (1985), Ionicstrength effect on heavy-metal adsorption by soil. Commun. Soil Sci. Plan., 16, 971-986.

Pombo, L., Salgado, V., Volkweiss, S., Klamt, E. (1989), Adsorção de níquel por dois solos: terra bruna estruturada similar e podzólico vermelho-amarelo. Pesqui. Agropecu. Bras., 24, 593-598.
Raij, B. van., Andrade, J.C., Cantarella, H., Quaggio, J.A. (2001), Análise química para avaliação de fertilidade de solos tropicais. Instituto Agronômico: Campinas.

Rovers, H., Camargo, A.O., Valadares, J.M.A.S. (1983), Níquel total e solúvel em DTPA em solos do Estado de São Paulo. Rev. Bras. Cienc. Solo, 7, $217-$ 220.

Scheidegger, A.M., Fendorf, M., Sparks, D. (1996), Mechanisms of nickel sorption on pyrophyllite: macrospcopic and microscopic approaches. Soil Soil Sci. Soc. Am. J., 60, 1763-1772.

Sen Gupta, S., Bhattacharyya, K.G. (2006), Adsorption of Ni(II) on clays. J. Colloid Interf. Sci., 295, 21-32.

Silveira, M.L.A., Alleoni, L.R.F., Casagrande, J.C., Camargo, O.A. (1999), Energia livre da adsorção de cobre em Latossolos ácricos. Sci. Agric. (Piracicaba, Braz.), 56, 1117-1122.

Silveira, M.L.A.; Alleoni, L.R.F. (2003), Copper adsorption in tropical oxisols. Braz. Arch. Biol. Techn., 46, 529-536.

Singh, T.S., Pant, K.K. (2004), Equilibrium, kinetics and thermodynamic studies for adsorption of As(III) on activated alumina. Sep. Purif. Technol., 36, 139147.

Soares M.R., Alleoni, L.R.F. (2008), Contribution of soil organic carbon to the ion exchange capacity of tropical soils. J. Sustain. Agr., 32, 439-462.

Soares, M.R., Alleoni, L.R.F., Casagrande, J.C. (2005), Parâmetros termodinâmicos da reação de adsorção de boro em solos altamente intemperizados. Quim. Nova, 28, 1014-1022.

Soares, M.R., Casagrande, J.C. (2009), Adsorção e modelos. In Tópicos em ciência do solo VI, ed. M.R., Ribeiro, C.W.A., Nascimento, J.R.B., Cantalice, M.R., Ribeiro Filho. SBCS, Viçosa, pp.71-201.

Soares, M.R., Casagrande, J.C., Mouta, E.R. (2009), Effects of soil solution parameters on cadmium adsorption by Brazilian variable charge soils. Commun. Soil Sci. Plan., 40, 2132-2151.

Soil Survey Staff (1999), Soil Taxonomy: a basic system of soil classification for making and interpreting soil surveys. United States Department of Agriculture and Natural Resources Conservation Service (Agriculture Handbook n.436), U.S. Government Printing Office, Washington.

Sparks, D.L. (1999), Kinetics and mechanisms of chemical reactions at the soil mineral/water interface. In Soil physical chemistry, ed. D.L. Sparks. CRC Press, New York, pp. 135-191.

Sposito, G. (1989), The Chemistry of Soils. Oxford, New York.

Suarez, D.L. (1999), Thermodynamics of the soil solution. In Soil physical chemistry, ed. D.L. Sparks, CRC Press, Boca Raton, pp. 97-134. 
Sunderman, F.W., Oskarson, A. (1991), Nickel. In Metals and their compounds in the environment: occurrence, analysis and biological relevance, ed. E. Merian, VCH, Weinheim, pp. 1101-1126.

Tamanini, C.R., Motta, A.C.V., Andreoli, C.V., Doetzer, B.H. (2008), Land reclamation recovery with the sewage sludge use. Braz. Arch. Biol. Techn., 51, 643-655.

Tan, K.H., Hajek, B.F., Barshad, I. (1986), Physical and mineralogical methods. In Methods of Soil Analysis, ed. A. Klute. SSSA, Madison, chapter 7.
Uren, N.C. (1992), Forms, reactions and availability of nickel in soils. Adv. Agron., 48, 141-203.

Wang, W.Z., Brusseau, M.L., Artiola, J.F. (1997), The use of calcium to facilitate desorption and removal of cadmium and nickel in subsurface soils. J. Contam. Hydrol., 25, 325-336.

Weber, O.L.S., Chitolina, J.C., Camargo, O.A., Alleoni, L.R.F. (2005), Cargas elétricas estruturais e variáveis de solos tropicais altamente intemperizados. Rev. Bras. Cienc. Solo, 29, 867-873. 